\title{
High Density Plantation in Saffron (Crocus sativus L.) for Achieving Higher Yields
}

\author{
Sabina Nasseer*, Shahina A. Nagoo, Niyaz A. Dar, Shabir Ahmad, \\ Ishfaq A. Abid, Gowhar Ali, Sabia and F.A. Nehvi
}

Saffron Research Station, Pampore, Sher-i-Kashmir University of Agricultural Sciences and Technology of Kashmir, India

*Corresponding author

\section{A B S T R A C T}

\section{Keywords}

High density, Daughter corm production

Article Info

Accepted: 07 April 2018 Available Online: 10 May 2018
The high density plantation approach is in vogue these days to mitigate the effects of decreasing area under the saffron cultivation. The approach has found wide adoption due to increase in the production and productivity of flowers as well as corms. A study was conducted wherein the graded and disease free corms were planted at different densities viz. 5 corms/hill $(25 X 15 \mathrm{~cm}), 10$ corms/ hill $(30 \times 20 \mathrm{~cm}), 12$ corms/hill $(30 \times 20 \mathrm{~cm})$ and 15 corms/hill at the density of $20 X 10 \mathrm{~cm}$ after following the recommended package of practices. It was found that the 5 corms/hill resulted in maximum daughter corm production, more number of leaves, higher flower production and hence more yields.

\section{Introduction}

Saffron (Crocus sativus L) is a slow growing perennial plant regenerating from regenerating from vegetative multiplication of its underground corms. Saffron is regarded as the most costly spice in the world being recognised as an anticancer medicinal herb (Gresta et al., 2008). It is widely known for its aroma, colour and medicinal properties.

Saffron is cultivated worldwide from Spain to Kashmir $\left(0^{\circ}-90^{\circ} \mathrm{E}\right.$ longitude) and $30^{\circ}-42^{\circ} \mathrm{N}$ latitude (Persia- England) (Anwar et al., 2011). Though it has gained popularity worldwide, yet its production is all the countries (except Iran) have declined. In spite of the fact that more area has been brought under its cultivation, the declining trend of production envisages use of alternate methods for increasing production. Being a vegetatively propagated crop, the timely availability of the bigger sized disease free corms is an indispensable input which forms the single most costly input in saffron cultivation. Saffron is made up of a complex mixture of volatile and non-volatile compounds that contribute to its overall aroma and flavour (Moraga et al., 2009).

\section{Materials and Methods}

Saffron corms $2.5-3 \mathrm{~cm}$ diameter having $>8 \mathrm{~g}$ weight were sorted out and subjected to the 
fungicide treatment of Carbendazime + Mancozeb (2.5 g/lt). The saffron corms were planted at a distance of $15 \mathrm{X} 25 \mathrm{~cm}$ spacing in a bed of $2 X 15 \mathrm{~cm}$ dimension. The corms were planted at the rate of $2 \mathrm{corm} / \mathrm{hill}, 3 \mathrm{corm} / \mathrm{hill}$, $4 \mathrm{corm} / \mathrm{hill}$ and $5 \mathrm{corm} / \mathrm{hill}$ and fertilisers were applied at the scheduled time and quantity. The sprinkler irrigation was applied in the month of August and September. The integrated nutrient management module of 120: 90: $80 \mathrm{kgs} / \mathrm{ha}$ was followed. The corms were hand sown at a depth of $15 \mathrm{~cm}$. Weeding and Hoeing were carried out for better corm development.

\section{Results and Discussion}

Under high density production system, saffron yield has considerably increased. A benefit: cost ratio of 4.28: 1 has been achieved which amounts to an average productivity of 11.88 $\mathrm{kg} /$ hectare compared to $6.37 \mathrm{~kg} /$ hectare under normal density over 4 years planting cycle (Table 2).

Table.1 Plant characteristics in terms of corm density

\begin{tabular}{|c|c|c|c|c|}
\hline $\begin{array}{c}\text { Corm density } \\
\text { (Corm/hill) }\end{array}$ & \multicolumn{2}{|c|}{ Number of flowers } & \multicolumn{2}{|c|}{$\begin{array}{c}\text { Number of daughter } \\
\text { corm/mother corm }\end{array}$} \\
\hline & 1st year & 2nd year & 1st year & 2nd year \\
\hline $\mathbf{5}$ & 400 & 423 & 2.04 & 2.14 \\
\hline $\mathbf{1 0}$ & 405 & 402 & 2.16 & 2.03 \\
\hline $\mathbf{1 2}$ & 412 & 406 & 2.20 & 1.87 \\
\hline $\mathbf{1 5}$ & 417 & 407 & 2.02 & 1.85 \\
\hline
\end{tabular}

Table.2 Yield characteristics with reference to corm density

\begin{tabular}{|c|c|c|c|c|}
\hline $\begin{array}{c}\text { Corm density } \\
\text { (corm /hill) }\end{array}$ & \multicolumn{2}{|c|}{ Corm yield/m } & \multicolumn{2}{c|}{ Yield(kg/ha) } \\
\hline & 1st year & 2nd year & 1st year & 2nd year \\
\hline $\mathbf{5}$ & 282.14 & 293 & 5.0 & 12.5 \\
\hline 10 & 315.27 & 310.14 & 7.5 & 11.0 \\
\hline 12 & 322.60 & 311.36 & 8.3 & 10.3 \\
\hline 15 & 335.42 & 312.42 & 8.9 & 9.50 \\
\hline
\end{tabular}

Study confirmed that under temperate conditions of Kashmir, corms planted at high densities viz., 10corm / hill, 12corm/hill and $15 \mathrm{corm} / \mathrm{hill}$ remain viable only up to two years.

The corms are destroyed due to overcrowding whereas corms planted 5corm / hill exhibited superiority by $86.49 \%$ over normal density of $1 \mathrm{corm} /$ hill (Table 1).

\section{References}

Abdullaev, F.I. 2002. Cancer chemopreventive and tumorocidal properties of saffron (Crocus sativus L). Experimental Biology and Medicine, 227: 20-25

Carmona, M., Zalacain, A., Salinas, M.R. and Alanso, G. I. 2007. A new approach to 
saffron aroma. Critical Review of Food Science Nutrition, 47: 145-159

Gathercoal, E.N. and Wirth, E.N. 1947. Pharmacognosy Lea and Febreger, Philadelphia $172 \mathrm{pp}$

Gresta, F., Lombardo, G.M., Siracusa, L. and Ruperto, G. 2008. Saffron an alternate crop for sustainable agricultural systems. A review. Agron. Sustain. Development. 28: 95-112

Kumar, R., Singh, V., Devi, K., Sharma, M., Singh, M.K. and Ahuja, P.S. 2009. State of Art of Saffron (Crocus sativus L). Agronomy: A Comprehensive Review. Food Rev. Int. 25: 44-85
Nehvi, F.A., Anwar Alam and Salwee Yasmeen. 2010. Saffron Farming in India. Financing Agriculture. 42(5): 916.

Padmavati, J. Kumar, Ch. P., Sarawathi, V.S., Saravanan, D., Lakshmi, I.A, Bindu, N.H.S. and Hemafaith, V. 2011. Pharmacological, Pharmacognostic and phytochemical review of saffron. International Journal of Pharmacological Technology. 3: 12141234.

Rios, J.L. Reico, M.C., Giner, R.M. and Manez, S. 1996. An update review of saffron and its active constituents. Phytotherm Research. 10: 189-193

\section{How to cite this article:}

Sabina Nasseer, Shahina A. Nagoo, Niyaz A. Dar, Shabir Ahmad, Ishfaq A. Abid, Gowhar Ali, Sabia and Nehvi, F.A. 2018. High Density Plantation in Saffron (Crocus sativus L.) for Achieving Higher Yields. Int.J.Curr.Microbiol.App.Sci. 7(05): 748-750.

doi: https://doi.org/10.20546/ijcmas.2018.705.091 